\title{
In vitro embryos production of oocytes selected based on follicular size and by brilliant cresyl blue staining
}

\section{Produção in vitro de embriões de oócitos selecionados baseados no tamanho folicular e por coloração com azul cresil brilhante}

\author{
Fabiana Dakkach de Almeida Barros ${ }^{1}$; Paulo Roberto Adona ${ }^{1 *}$; \\ Samuel Guemra'; ${ }^{1}$ Tiago Henrique Camara De Bem²; Paulo Sergio Monzani²; \\ Claudia Lima Verde Leal ${ }^{2}$
}

\begin{abstract}
We evaluated the competence of bovine oocytes via morphological selection associated with follicular diameter and by brilliant cresyl blue (BCB) staining, in order to improve oocyte selection and the efficiency of in vitro embryo production. Follicles with small $(2<4 \mathrm{~mm})$, large $(4-8 \mathrm{~mm})$ or mixed $(2-8 \mathrm{~mm})$ diameters were aspirated from slaughterhouse ovaries. Next, the morphologically categorized oocytes were stained and evaluated with $26 \mu \mathrm{M}$ of BCB $(90 \mathrm{~min}$ ), followed by an assessment of in vitro maturation (MII) and blastocyst production. Oocytes from the large $(61.1 \pm 3.9 \%)$ and mixed $(52.9 \pm 4.6 \%)$ follicular groups showed comparable $(\mathrm{p}>0,05) \mathrm{BCB}+$ rates, but both differed $(\mathrm{p}<0.05)$ as compared to the small-diameter group $(41.0 \pm 4.5 \%)$. Between the $\mathrm{BCB}+$ and $\mathrm{BCB}-$ oocytes, there was no difference $(\mathrm{p}>0,05)$ in MII rate in the mixed (respectively $86.7 \pm 3.4$ and $75.8 \pm 2.2$ ), large (respectively $89.4 \pm 2.6$ and $79.7 \pm 2.3$ ) and small (respectively $76.7 \pm 2.9$ and $67.2 \pm 2.5$ ) diameter groups. Comparing BCB ( + and -$)$ oocytes, we observed $(\mathrm{p}>0,05)$ no change in the percentage of embryos in the large group (respectively $67.3 \pm 3.3$ and $53.5 \pm 5.8$ ) and in the small group (respectively $43.8 \pm 5.3$ and $33.9 \pm 2.2$ ), but there was a difference $(\mathrm{p}<0.05)$ in the mixed group (respectively 57.8 \pm 3.9 and $39.6 \pm 7.5$ ). Furthermore, when we compared between follicular groups, the BCB+/largediameter group $(61.1 \pm 3.9 \%)$ had a significant higher percentage of embryos $(\mathrm{p}<0.05)$ than the smalldiameter $\mathrm{BCB}+(43.8 \pm 5.3)$ groups. To conclude, selection procedures that use follicle size and/or $\mathrm{BCB}$ staining may be used as an additional tool to improve the in vitro production of embryos.
\end{abstract}

Key words: Blastocysts. Competence. Follicle. Maturation. Morphology.

\section{Resumo}

Avaliou-se a competência de oócitos bovinos através da seleção morfológica associada ao diâmetro folicular e pela coloração azul cresil brilhante (BCB), a fim de melhorar a seleção de oócitos e a eficiência da produção in vitro de embriões. Folículos com diâmetro pequeno $(2<4 \mathrm{~mm})$, grande (4-8 $\mathrm{mm}$ ) ou misto (2-8 $\mathrm{mm}$ ) foram aspirados de ovários de matadouro. Em seguida, os oócitos classificados morfologicamente foram corados e avaliados com $26 \mu \mathrm{M}$ de BCB (90 min), seguido de uma avaliação da maturação in vitro (MII) e produção de blastocisto. Os oócitos dos grupos folículo grande $(61,1 \pm$ $3,9 \%)$ e misto $(52,9 \pm 4,6 \%)$ apresentaram taxas de $\mathrm{BCB}+$ comparáveis $(\mathrm{p}>0,05)$, mas ambos diferiram

\footnotetext{
1 Profs. Pesquisadores, Pós-Graduação em Saúde e Produção de Ruminantes, Universidade Norte do Paraná, UNOPAR, Arapongas, PR, Brasil. E-mail: fabianabarros.veterinaria@hotmail.com; paulo_adona@yahoo.com.br; samuel.guemra@hotmail.com

2 Profs. Pesquisadores, Universidade de São Paulo, USP, Departamento de Medicina Veterinária. Pirassununga, SP, Brasil. E-mail: tiagodebem@yahoo.com.br; monzani.paulo@gmail.com; clvleal@usp.br

* Author for correspondence
} 
$(\mathrm{p}<0,05)$ em relação ao grupo folículo pequeno $(41,0 \pm 4,5 \%)$. Entre os oócitos $\mathrm{BCB}+$ e $\mathrm{BCB}-$, não houve diferença $(\mathrm{p}>0,05)$ na taxa de MII nos grupos mistos (respectivamente 86,7 $\pm 3,4$ e 75,8 $\pm 2,2$ ), grande (respectivamente 89,4 $\pm 2,6$ e 79,7 $\pm 2,3$ ) e pequeno (respectivamente 76,7 $\pm 2,9$ e 67,2 $\pm 2,5$ ). Comparando os oócitos BCB ( + e -), não observamos alteração $(\mathrm{p}>0,05)$ na porcentagem de embriões no grupo grande (respectivamente 67,3 $\pm 3,3$ e 53,5 $\pm 5,8$ ) e no grupo pequeno (respectivamente 43,8 \pm $5,3$ e 33,9 $\pm 2,2)$, mas há houve diferença $(\mathrm{p}<0,05)$ no grupo misto (respectivamente $57,8 \pm 3,9$ e 39,6 $\pm 7,5)$. Além disso, quando comparamos os grupos foliculares, o grupo $\mathrm{BCB}+$ /grande $(61,1 \pm 3,9 \%)$ apresentou uma porcentagem significativamente maior de embriões $(\mathrm{p}<0,05)$ do que o grupo $\mathrm{BCB}+/$ pequeno $(43,8 \pm 5,3)$. Para concluir, os procedimentos de seleção que usam tamanho do folículo e/ou coloração com BCB podem ser usados como uma ferramenta adicional para melhorar a produção in vitro de embriões.

Palavras-chave: Blastocisto. Competência. Folículo. Maturação. Morfologia.

\section{Introduction}

Oocyte competence is progressively acquired towards the end of folliculogenesis, when many cellular and molecular changes occur (ADONA et al., 2016; LIU et al., 2018). Such changes can influence various components of maturation, such as the quality of the follicular environment, follicle size, morphology of the cumulus-oocyte complex, and maturation conditions (DE BEM et al., 2014; SOARES et al., 2018). Therefore, the selection of competent oocytes is essential for the success of in vitro production (IVP).

In contemporary procedures, oocytes are selected for in vitro maturation (IVM) based only on the assessment of morphological features such as cumulus thickness and compactness/homogeneity of the ooplasm. Although the morphological characterization of oocytes is acceptable to assess nuclear maturation $( \pm 80 \%)$ and embryonic development $( \pm 45 \%)$, it does not directly evaluate the quality of oocytes for full developmental competence, with as end-point the delivery of healthy offspring (DE BEM et al., 2014; PONTES et al., 2011). Thus, morphological assessment only considers the indirect features of oocyte quality, such as cytoplasmic homogeneity, and the amount and quality of somatic cells in the cumulus-oocyte complex (BAKRI et al., 2016). Although this approach is widely used, it is quite subjective and its accuracy is limited, because some oocytes with normal morphology might be in an early stage of degeneration, leading to heterogeneous results (IWASAKI et al., 2018). Besides morphological evaluation of the oocytes, follicular characteristics have been used as well to improve IVP (DE BEM et al., 2014; IWASAKI et al., 2018). A previous study assessed the competence of bovine oocytes from varying follicles sizes and demonstrated that large follicles increased oocyte quality and blastocyst production, as compared to medium and small follicles (LABRECQUE et al., 2016). Accordingly, it is of interest to implement assessments of morphology and follicle size in non-invasive methods for selecting the best oocytes.

Using brilliant cresyl blue (BCB) to highlight characteristics that aid in selecting oocytes, could support the aforementioned approach, since it is simple, non-invasive, and does not impair embryonic development (SU et al., 2012). In brief, BCB staining assesses oocyte metabolism (DUARTE ALCOBA et al., 2018) by determining the activity of glucose6-phosphate dehydrogenase (G6PDH), an enzyme synthesized in growing oocytes, but inactive in oocytes that have completed their growth (BOLS et al., 2012; OPIELA; KATSKA-KSIAZKIEWICZ, 2013). This makes it possible to differentiate between different developmental phases of oocytes, as the $\mathrm{BCB}$ dye is metabolized and reduced to a less intense color by G6PDH (BRAGANCA et al., 2018; SU et al., 2012). Thus, blue staining of the oocyte cytoplasm indicates low specific activity of G6PDH (classified as $\mathrm{BCB}+$ ), and is indicative of more competent oocytes (IWASAKI et al., 2018). 
Conversely, the absence of staining is classified as $\mathrm{BCB}-$ and indicates high G6PDH activity, identifying less competent oocytes (MIRSHAMSI et al., 2013; SU et al., 2012).

Our aim was to assess the competence of bovine oocytes based on an investigation of morphology and follicle size, in conjunction with BCB staining. Our study may in time lead to an enhanced oocyte selection and efficiency in producing IVP embryos. However, to routinely use these oocyte selection criteria, additional research in cattle is required for a more refined understanding of oocyte competence.

\section{Materials and Methods}

All chemicals were acquired from Sigma Chemical Company (St Louis, MO, USA), unless stated otherwise.

\section{Ethics statement}

The study was approved by the Committee of Ethics for the use of animals ( $n^{\circ} 002 / 17$ ), according to the norms formulated by the Brazilian Council for the Control of Animal Experimentation.

\section{Oocyte selection}

We collected 40 to 60 ovaries per day from a local bovine slaughterhouse, which were in turn transported $\left(3 \mathrm{~h}, 25-30^{\circ} \mathrm{C}\right)$ in physiological solution ( $\mathrm{Na} \mathrm{Cl}, 0.9 \%$ ), containing $100 \mathrm{U} \mathrm{mL}^{-1}$ penicillin and $100 \mathrm{U} \mathrm{mL}^{-1}$ streptomycin. Next, we measured the follicles with digital calipers and classified them according to their diameter: 1) oocytes from follicles measuring $2<4 \mathrm{~mm}$ (small), 2) oocytes from follicles measuring 4-8 $\mathrm{mm}$ (large), and 3 ) oocytes from follicles measuring 2-8 $\mathrm{mm}$ diameter (mixed). In turn, we selected aspirated oocytes from each group for morphological evaluation, using a stereomicroscope (Nikon Instruments Inc. USA, SMZ1000). Only those oocytes classified as grade I and II, containing more than three layers of cumulus cells and uniform cytoplasm, were used (DE BEM et al., 2014; DE LOOS et al., 1992).

\section{$B C B$ staining and oocyte evaluation}

We classified oocytes based on follicular diameter and morphological criteria (as previously described), followed by an evaluation via $\mathrm{BCB}$ staining. In order to evaluate oocytes with $\mathrm{BCB}$ staining, they were incubated $\left(90 \mathrm{~min}, 38.5^{\circ} \mathrm{C}, 5 \%\right.$ $\mathrm{CO}_{2}$ ) with $26 \mu \mathrm{M}$ BCB (B5388) in TCM Hepes 199 medium (M3769), containing 0.1\% polyvinyl alcohol (PVA). In turn, the oocytes were classified under a stereomicroscope (SMZ1000) as $\mathrm{BCB}+$ (blue cytoplasm) or as BCB- (no staining was present) (RODRIGUEZ-GONZALEZ et al., 2002).

\section{In vitro maturation of oocytes}

Oocytes that were classified by follicular diameter, morphology and $\mathrm{BCB}$ staining were consequentially matured in vitro. In addition, a group of oocytes that was evaluated without being exposed to BCB (BCB-free) was also matured in vitro. We performed the maturation in TCM 199 medium, containing bicarbonate (M4530), with $10 \%$ fetal bovine serum, $5.0 \mu \mathrm{g} \mathrm{mL} \mathrm{m}^{-1}$ luteinizing hormone, $0.5 \mu \mathrm{g} \mathrm{mL}^{-1}$ follicle stimulating hormone (Bioniche Animal Health, USA), $50 \mu \mathrm{g} \mathrm{mL}$ gentamicin, $100 \mu \mathrm{M}$ cystamine, and $0.2 \mu \mathrm{M}$ pyruvate. The oocytes were matured in vitro (38.5 ${ }^{\circ} \mathrm{C}, 5 \% \mathrm{CO}_{2}$ ) for $22 \mathrm{~h}$ in droplets of $100 \mu \mathrm{L}$ on a Petri dish (Corning Incorporated, USA, 430166), under mineral oil (SOVERNIGO et al., 2017).

Assessment of nuclear maturation by fluorescent staining of chromatin and microtubules

After $22 \mathrm{~h}$ of maturation, oocytes were denuded in PBS (0.1\% PVA) by vortexing (5 min) at maximum speed. The oocytes were washed three times (PBS, $0.1 \%$ PVA) and fixed in $3 \%$ paraformaldehyde 
in PBS $(0.6 \%$ triton $\mathrm{X}-100)$ for $1 \mathrm{~h}$ and blocked in $3 \%$ goat serum in PBS (45 min). Next, we stained the oocytes with primary anti-alpha tubulin antibody conjugated with FITC (P5282; 1:100) and propidium iodide ( $\mathrm{P} 4170 ; 10 \mu \mathrm{g} / \mathrm{mL})$ for $1 \mathrm{~h}$, as was previously described (ADONA et al., 2008). Microtubule staining was visualized in the cytoplasm to evaluate changes in the meiotic spindle plate, and together with chromatin staining, was used to classify oocytes into germinal vesicle, metaphase I, anaphase I, telophase I, or metaphase II stages. Imaging of the stained oocytes was performed using a Camera Infinity (Lumenera Corporation, Canada), coupled to an epifluorescence microscope (Nikon Instruments Inc. USA, Eclipse Ti) that was fitted with UV-2A (346-460 nm) and B-2E/C (495-519 $\mathrm{nm}$ ) filters (SOVERNIGO et al., 2017).

\section{In vitro production of embryos}

Oocytes that were classified according to follicular diameter, morphology and BCB staining, and that were consequentially matured in vitro, were fertilized to evaluate the in vitro production of embryos. To this end, we processed semen using the density gradient approach with BoviPure (Nidacon International AB, Sweden). The in vitro fertilization was performed over a period of $18 \mathrm{~h}$ in Tyrode's albumin, lactate and pyruvate (TALP) medium, supplemented with $2 \mathrm{mM}$ penicillamine, $1 \mathrm{mM}$ hypotaurine, $250 \mathrm{mM}$ epinephrine, and $20 \mu \mathrm{g} \mathrm{mL}^{-1}$ heparin (167 IU mg-1) (PARRISH, 2014; SOVERNIGO et al., 2017). Oocytes and spermatozoa $\left(2 \times 10^{6}\right.$ cells $\left./ \mathrm{mL}\right)$ were cultured $(18$ h) in droplets of $100 \mu \mathrm{L}$ (TALP) under mineral oil in Petri dishes (Corning, 430166). The generated zygotes were denuded by pipetting and in turn cultured in vitro (IVC) in Synthetic Oviduct Fluid (SOF) medium $(2.5 \%$ FBS, $5 \mathrm{mg}$ BSA, $0.2 \mu \mathrm{M}$ pyruvate, and $50 \mu \mathrm{g} \mathrm{mL} \mathrm{m}^{-1}$ gentamicin) at $38.5^{\circ} \mathrm{C}$ in
5\% $\mathrm{CO}_{2}$ (HOLM et al., 1999; SOVERNIGO et al., 2017). Next, we evaluated the cleavage rates $48 \mathrm{~h}$ post insemination (hpi). In addition, blastocyst rates were evaluated $168 \mathrm{hpi}$ and hatching was assessed 192 hpi. At this time, blastocysts were fixed in 3\% paraformaldehyde with $0.1 \%$ PVA for $15 \mathrm{~min}$ and cells were counted (SOVERNIGO et al., 2017).

\section{Statistical analyses}

All statistical analyses were performed using BioEstat 5.3 software (Institute Mamirauá, Brazil). We used the Kolmogorov-Smirnov test to assess normality of the data. Furthermore, BCB staining of oocytes was evaluated using the chi-square test. Finally, maturation, cleavage, blastocysts, hatching rates, and total cell numbers in blastocysts were analyzed using the Kruskal-Wallis test. For all analyses, $\mathrm{p}<0.05$ was considered significant and the results are presented as the means \pm standard deviation (SD).

\section{Results}

\section{$B C B$ staining}

We observed no difference $(p>0.05)$ in the percentage of $\mathrm{BCB}+$ oocytes when comparing between the mixed and large diameter groups. However, both these groups had significantly more $\mathrm{BCB}+$ oocytes $(\mathrm{p}<0.05)$ than the small diameter group (Table 1). When we compared the fractions of $\mathrm{BCB}+$ and $\mathrm{BCB}-$ oocytes within their respective size groups, significant differences $(\mathrm{p}<0.05)$ were observed in the large diameter and small diameter groups (Table 1). In contrast, there was no difference $(\mathrm{p}>0.05)$ between $\mathrm{BCB}+$ and $\mathrm{BCB}-$ in the mixed size group (Table 1). In total, 2.958 oocytes were used in six experimental repeats. 
Table 1. Percentages of oocytes from follicles of different diameters, evaluated by brilliant cresyl blue (BCB).

\begin{tabular}{lccccc}
\hline \multirow{2}{*}{ Groups } & Oocytes & \multicolumn{2}{c}{ BCB $(+)$} & \multicolumn{2}{c}{ BCB (-) } \\
\cline { 2 - 6 } & $\mathrm{N}^{\mathrm{o}}$ & $\mathrm{N}^{\mathrm{o}}$ & $\% \pm \mathrm{SD}$ & $\mathrm{N}^{\mathrm{o}}$ & $\% \pm \mathrm{SD}$ \\
\hline Mixed $(2-8 \mathrm{~mm})$ & 1200 & 635 & $52.9 \pm 4.6^{\mathrm{a}}$ & 565 & $47.1 \pm 4.6^{\mathrm{a}}$ \\
Large $(4-8 \mathrm{~mm})$ & 980 & 599 & $61.1 \pm 3.9^{\mathrm{a}}$ & 381 & $38.9 \pm 3.9^{\mathrm{a} *}$ \\
Small $(2<4 \mathrm{~mm})$ & 778 & 318 & $40.9 \pm 4.5^{\mathrm{b}}$ & 460 & $59.1 \pm 4.5^{\mathrm{b}}{ }^{\mathrm{b}}$ \\
\hline
\end{tabular}

Different letters in the same column $(a-b)$ indicate a significant difference $(p<0.05)$ between the oocyte groups.

* Indicate a significant difference $(\mathrm{p}<0.05)$ between BCB (+ and -) oocytes in large follicle groups.

$\dagger$ Indicate a significant difference $(\mathrm{p}<0.05)$ between BCB (+ and -) oocytes in the small follicle groups.

The percentage $(\%)$ and the standard deviation of the mean $( \pm \mathrm{SD})$ are based on six experimental repeats.

\section{Nuclear maturation}

When we compared between $\mathrm{BCB}(+$ and -) oocytes within the same size group, we observed no significant differences $(\mathrm{p}>0.05)$ in maturation rates in the mixed (respectively $86.7 \pm 3.4$ and $75.8 \pm$ 2.2), large (respectively $89.4 \pm 2.6$ and $79.7 \pm 2.3$ ), and in the small (respectively $76.7 \pm 2.9$ and 67.2 \pm 2.5 ) diameter groups (Figure 1). We observed no difference $(\mathrm{p}>0.05)$ in the percentage of $\mathrm{BCB}+$ oocytes when comparing between the large $(89.4 \pm$ $2.6 \%)$ and mixed $(86.7 \pm 3.4 \%)$ diameter groups. However, only the large group showed significantly more $\mathrm{BCB}+$ oocytes $(\mathrm{p}<0.05)$ than the small diameter group $(76.7 \pm 2.9 \%)$. (Figure 1$)$. The maturation rate in the BCB-free group $(83.8 \pm 3.4)$ was similar $(\mathrm{p}>0.05)$ to the rates in the $\mathrm{BCB}+$ oocytes with a mixed $(86.7 \pm 3.4)$, large $(89.4 \pm 2.6)$ and small $(76.7 \pm 2.9)$ diameter (Figure 1). Furthermore, microtubule staining was observed in the cytoplasm of oocytes ( $\mathrm{BCB}+$ and $\mathrm{BCB}-$ ) belonging to the mixed, large, small and $\mathrm{BCB}$-free groups. A stronger intensity was observed in microtubules close to the chromosomes (Figure 2). However, neither anomalies nor qualitative differences were detected in the spindle or the metaphase plate, regardless of the group or treatment (Figure 2). In addition, all matured oocytes presented a metaphase plate and first polar body (1BP). Of note, the immature oocytes were in early stages of the meiotic cycle, as well as metaphase I, anaphase I and telophase I. In total, we used 641 oocytes used in three biological experimental repeats.

\section{IVP embryo}

Comparing $\mathrm{BCB}+$ and $\mathrm{BCB}-$ oocytes within the same size group, we observed no change $(p>0.05)$ in cleavage rates in the large and small groups. When evaluating differences between mixed, large, small and BCB-free groups, it became apparent that the cleavage rate of the large group $(\mathrm{BCB}+)$ was higher $(p<0.05)$ than the mixed (BCB-), small $(B C B+$ and $\mathrm{BCB}-$ ) and $\mathrm{BCB}-$ free groups (Table 2). In terms of embryonic production, there was no difference ( $p>0.05)$ in the percentage of blastocysts generated from oocytes $(\mathrm{BCB}+$ or $\mathrm{BCB}-$ ) in the large and small groups, but there was no significant difference $(p<0.05)$ in the mixed group for $\mathrm{BCB}+$ and $\mathrm{BCB}-$ oocytes. Continuing along this line, embryonic development rates in the large group $(\mathrm{BCB}+)$ were higher $(p<0.05)$ than those in the BCB-free, mixed $(\mathrm{BCB}-)$ and small $(\mathrm{BCB}+$ and $\mathrm{BCB}-$ ) groups (Table $2)$. There was however no change $(p>0.05)$ in the percentage of hatched embryos and in the mean number of cells in hatched blastocysts (Table 3), irrespective of group or oocyte staining $(\mathrm{BCB}+$ and BCB-). 966 oocytes were used in four experimental repeats. 
Figure 1. Nuclear maturation rates of oocytes from follicles of different diameters, evaluated according to Brilliant Cresyl Blue (BCB). Different phases of meiosis: metaphase I, anaphase I, telophase I (MI-TI) and metaphase II (MII). Results of three experimental repeats.

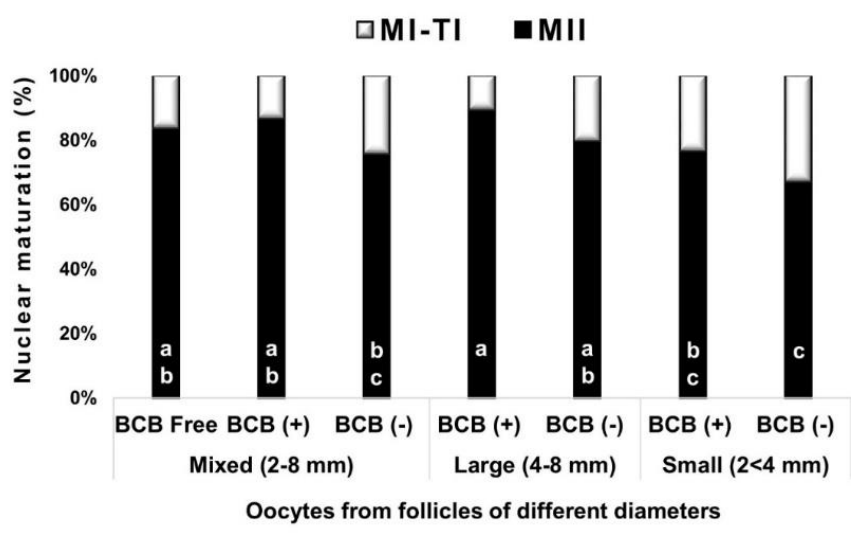

Figure 2. Representative images of the stages of nuclear maturation of oocytes from follicles of different diameters, evaluated with Brilliant Cresyl Blue. The arrows are pointing the position of the microtubules stained in green and the chromatin in red. The yellow arrow points to the first polar corpuscle.

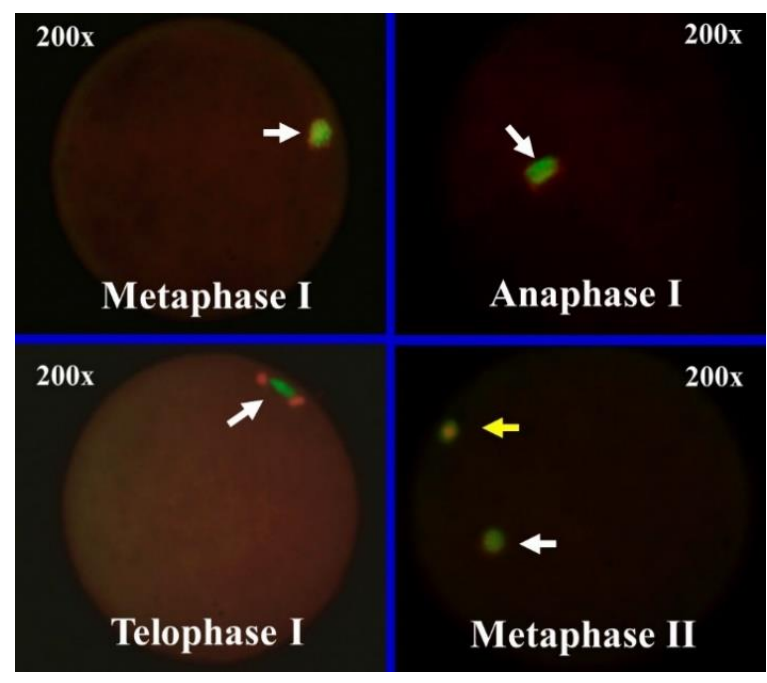

Table 2. Embryonic development rates in oocytes from follicles of different diameters, following brilliant cresyl blue (BCB) staining.

\begin{tabular}{|c|c|c|c|c|c|c|}
\hline \multirow{2}{*}{$\begin{array}{c}\text { Groups } \\
\mathrm{N}^{\mathrm{o}} \\
\end{array}$} & & \multirow{2}{*}{$\begin{array}{c}\text { Oocytes } \\
\mathrm{N}^{\mathrm{o}} \\
\end{array}$} & \multicolumn{2}{|c|}{ Cleavage D2* } & \multicolumn{2}{|c|}{ Blastocyst D7* } \\
\hline & & & $\% \pm \mathrm{SD}$ & $\mathrm{N}^{0}$ & $\% \pm \mathrm{SD}$ & \\
\hline \multirow{3}{*}{ Mixed (2-8 mm) } & BCB Free & 105 & 83 & $79.0 \pm 3.6^{\mathrm{bc}}$ & 50 & $47.6 \pm 5.2^{\mathrm{bcd}}$ \\
\hline & $\mathrm{BCB}(+)$ & 216 & 186 & $86.1 \pm 1.7^{\mathrm{ab}}$ & 125 & $57.8 \pm 3.9^{\mathrm{ab}}$ \\
\hline & BCB (-) & 192 & 146 & $76.0 \pm 3.1^{\mathrm{bc}}$ & 76 & $39.6 \pm 7.5^{\mathrm{cd}}$ \\
\hline \multirow{2}{*}{ Large (4-8 mm) } & $\mathrm{BCB}(+)$ & 153 & 141 & $92.1 \pm 4.0^{\mathrm{a}}$ & 103 & $67.3 \pm 3.3^{\mathrm{a}}$ \\
\hline & BCB (-) & 99 & 80 & $80.8 \pm 2.8^{\mathrm{abc}}$ & 53 & $53.5 \pm 5.8^{\mathrm{abc}}$ \\
\hline \multirow{2}{*}{ Small $(2<4$ mm $)$} & $\mathrm{BCB}(+)$ & 89 & 70 & $78.6 \pm 1.7^{\mathrm{bc}}$ & 39 & $43.8 \pm 5.3^{\text {bd }}$ \\
\hline & BCB (-) & 112 & 79 & $70.5 \pm 4.2^{\mathrm{c}}$ & 38 & $33.9 \pm 2.2^{\mathrm{d}}$ \\
\hline
\end{tabular}

Different letters $(\mathrm{a}-\mathrm{d})$ in the same column indicate significant changes $(\mathrm{p}<0.05)$. The percentage $(\%)$ and the standard deviation of the mean $( \pm \mathrm{SD})$ are based on the results of four experimental repeats. *Days after fertilization (D). 
Table 3. Percentage of embryos hatched from oocytes from follicles of different diameters, following Brilliant Cresyl Blue (BCB) staining.

\begin{tabular}{lccccc}
\hline \multirow{2}{*}{ Groups } & & \multicolumn{2}{c}{ Hatching D8 $^{*}$} & Cells D8 $^{* 1}$ \\
\cline { 3 - 6 } & & $\mathrm{N}^{\circ}$ & $\mathrm{N}^{\circ}$ & $\% \pm \mathrm{SD}$ & $\mathrm{N}^{\circ}( \pm \mathrm{SD})$ \\
\hline \multirow{3}{*}{ Mixed (2-8 mm) } & BCB Free & 50 & 35 & $70.0 \pm 2.7$ & $188( \pm 53)$ \\
& BCB (+) & 125 & 89 & $71.2 \pm 7.4$ & $196( \pm 57)$ \\
& BCB (-) & 76 & 55 & $72.3 \pm 6.0$ & $189( \pm 61)$ \\
\hline \multirow{2}{*}{ Large (4-8 mm) } & BCB (+) & 103 & 78 & $75.7 \pm 1.4$ & $199( \pm 65)$ \\
& BCB (-) & 53 & 38 & $71.7 \pm 1.4$ & $189( \pm 50)$ \\
\hline \multirow{2}{*}{ Small $(2<4 \mathrm{~mm})$} & BCB (+) & 39 & 27 & $69.2 \pm 6.6$ & $191( \pm 56)$ \\
& BCB (-) & 38 & 26 & $68.4 \pm 1.6$ & $190( \pm 55)$ \\
\hline
\end{tabular}

There was no significant difference between the oocyte groups $(\mathrm{p}<0.05)$. The percentages $(\%)$ and the standard deviations $( \pm \mathrm{SD})$ are based on four experimental repeats. *Days after fertilization (D). ${ }^{1}$ Number of cells from hatched embryos.

\section{Discussion}

The BCB staining results in this work highlight a higher proportion of $\mathrm{BCB}+$ oocytes in large follicles, as compared to small follicles, suggesting that larger follicles possess more competent oocytes. This is in support with other studies, which suggest that the $\mathrm{BCB}+$ rate in oocytes from large follicles coincides with a reduced G6PDH activity (the inverse is observed for small follicles, which constitute a higher fraction of BCB- oocytes) (ALM et al., 2005; LABRECQUE et al., 2016). The reduced $\mathrm{G} 6 \mathrm{PDH}$ activity in $\mathrm{BCB}+$ oocytes suggests that these oocytes have already completed, or have nearly completed, their growth phase (BRAGANCA et al., 2018; MOHAMMADI-SANGCHESHMEH et al., 2012) and would consequentially be more competent (BLONDIN et al., 2002). Therefore, the competence of oocytes is associated with the end of the growth phase, when the oocyte has completed almost all the steps required for ovulation. In this study, we observed in the mixed group that BCB+ oocytes were able to increase embryonic production as compared to $\mathrm{BCB}$ - oocytes.

It has been suggested that more $\mathrm{BCB}+$ oocytes stem from large follicles, as compared to small follicles, and that the $\mathrm{BCB}+$ staining of oocytes might also be related to their own diameter, rather than just the size of their respective progenitor follicles (KARAMI SHABANKAREH, et al., 2014; PUJOL et al., 2004). In the study conducted by Castaneda et al. (2013), oocyte diameter was not a determining factor of whether an oocyte stained $\mathrm{BCB}+$ or $\mathrm{BCB}-$. However, they did observe a variation of $\mathrm{BCB}$ staining related to oocyte diameter in one of the replicates, which might be linked to the variability among slaughtered animals, resulting from factors such as race, age and physiological status.

Follicle and oocyte diameters, as well as the variability between animals (race, age and physiological status), may be related to the developmental competence of oocytes (CASTANEDA et al., 2013; DE BEM et al., 2014). Therefore, the percentage of BCB staining in oocytes can be linked to, and potentially affected by, a great number of variables and the interactions between them. In this study, evaluating the diameter of the oocytes was not a point of focus, as we selected solely according to morphology, follicle size and the interaction between follicle size and the BCB staining. Our results indicate that the large follicles contain competent oocytes, and that most of these stain $\mathrm{BCB}+$.

Furthermore, we observed that nuclear maturation (MII) did not differ between $\mathrm{BCB}+$ and $\mathrm{BCB}-$ oocytes from the mixed, large, and small diameter 
groups. These results (MII) do not support previous studies, where it was shown that $\mathrm{BCB}+$ oocytes are more competent to complete MII (ALM et al., 2005; LIU et al., 2018; RODRIGUEZ-GONZALEZ et al., 2002). Although our results on maturation (MII) did not differ between the $\mathrm{BCB}+$ and $\mathrm{BCB}-$ oocytes within the same follicular group, there were marked differences between the follicular groups. More specifically, the $\mathrm{BCB}+$ oocytes of the large group were superior in the MII ratio to the mixed group $\mathrm{BCB}-$ and to the small group $\mathrm{BCB}+$ and $\mathrm{BCB}-$, suggesting that oocytes from the large $\mathrm{BCB}+$ group are more competent to complete maturation (MII). When we compared between BCB-exposed and BCB-free oocytes, it was apparent that MII remained unchanged, suggesting that the exposure to $\mathrm{BCB}$ itself was not harmful to the oocytes. This observation is supported by previous work in cattle (ALM et al., 2005).

The removal of oocytes from small follicles before capacitation is associated with a markedly reduced MII rate, which is caused by the early interruption of folliculogenesis (HYTTEL et al., 1997). Of interest, the increase of the follicular diameter has been linked to the expansion of cells in the cumulus and to the in vitro maturation of bovine oocytes (KAUFFOLD et al., 2005). In our study, the cleavage rate followed a comparable pattern as the MII rate, and similar results were reported in other study (ALM et al., 2005; FATHI et al., 2017). Continuing along this line, we noted increased cleavage rates in the $\mathrm{BCB}+$ oocytes of the large group, as compared to the small and $\mathrm{BCB}$-free groups. Of note, the follicular origin in conjunction or not with the BCB staining was positively related to cleavage rates and development of the embryos (CATALA et al., 2011; DE BEM et al., 2014; MIRSHAMSI et al., 2013), and our results corroborate these previous observations. The developmental competence of oocytes is gradually acquired and increases as follicular development proceeds (GANDOLFI; GANDOLFI, 2001), and satisfactory developmental competence in bovine is acquired with a follicular diameter of $3 \mathrm{~mm}$ and more (GANDOLFI; GANDOLFI, 2001). We discovered that the follicular size of oocytes affects cleavage and blastocyst rates, regardless of their $\mathrm{BCB}$ classification, whereas the proportion of hatched blastocysts and the mean number of embryonic cells did not differ between treatments. These results are partly consistent with those of other studies, which suggest that oocytes from larger follicles are more competent (DE BEM et al., 2014), and that BCB+ oocytes result in higher blastocyst rates as compared to BCB- oocytes (FANG et al., 2019).

The in vitro embryo production (blastocyst) rates of this study differed significantly when they were generated from either small or large follicles, even without taking into consideration the BCB staining data. In our work, the oocytes from large follicles generated approximately $38 \%$ more blastocysts than those from small follicles. Here as well, our data are in line with former work (DE BEM et al., 2014; KIM et al., 2010). Building on this, the estimation of IVP embryos regarding BCB assessment presented an approximate increase of $27 \% \mathrm{BCB}+$ oocytes (not taking into consideration follicle size). These data suggest that $\mathrm{BCB}$ staining highlights the most competent oocytes, irrespective of follicular size. Our results are consistent with those of other studies, where $\mathrm{BCB}+$ oocytes had a reduced G6PDH activity, and where oocytes from large follicles had probably completed their growth (DE BEM et al., 2014; FANG et al., 2019; KIM et al., 2010).

\section{Conclusion}

In conclusion, oocytes derived from large follicles are more suitable for in vitro embryonic development than oocytes from small follicles. Furthermore, screening oocytes based on a BCB staining in the mixed diameter group resulted in the selection of the most competent oocytes for 
embryonic IVP. In mixed, a selection based on follicle size and BCB staining could be used as an additional tool to enhance IVP embryos. However, more research is required to assess pregnancy rates, and the success of development to term.

\section{References}

ADONA, P. R.; LEAL, C. L.; BIASE, F. H.; DE BEM, T. H.; MESQUITA, L. G.; MEIRELLES, F. V.; FERRAZ, A. L.; FURLAN, L. R.; MONZANI, P. S.; GUEMRA, $\mathrm{S}$. In vitro maturation alters gene expression in bovine oocytes. Zygote, Cambridge, v. 24, n. 4, p. 624-633, 2016. DOI: $10.1017 / \mathrm{S} 0967199415000672$

ADONA, P. R.; PIRES, P. R.; QUETGLAS, M. D.; SCHWARZ, K. R.; LEAL, C. L. Prematuration of bovine oocytes with butyrolactone I: effects on meiosis progression, cytoskeleton, organelle distribution and embryo development. Animal Reproduction Science, Netherlands, v. 108, n. 1, p. 49-65, 2008. DOI: 10.1016/j. anireprosci.2007.07.002

ALM, H.; TORNER, H.; LOHRKE, B.; VIERGUTZ, T.; GHONEIM, I. M.; KANITZ, W. Bovine blastocyst development rate in vitro is influenced by selection of oocytes by brillant cresyl blue staining before IVM as indicator for glucose-6-phosphate dehydrogenase activity. Theriogenology, New York, v. 63, n. 8, p. 21942205, 2005. DOI: 10.1016/j.theriogenology.2004.09.050

BAKRI, N. M.; IBRAHIM, S. F.; OSMAN, N. A.; HASAN, N.; JAFFAR, F. H.; RAHMAN, Z. A.; OSMAN, K. Embryo apoptosis identification: Oocyte grade or cleavage stage? Saudi Journal Biological Sciences, Riyaḍ, v. 23, n. 1, p. 50-55, 2016. DOI: 10.1016/j. sjbs.2015.10.023

BLONDIN, P.; BOUSQUET, D.; TWAGIRAMUNGU, H.; BARNES, F.; SIRARD, M. A. Manipulation of follicular development to produce developmentally competent bovine oocytes. Biology Reproduction, New York, v. 66, n. 1, p. 38-43, 2002.

BOLS, P.; JORSSEN, E.; GOOVAERTS, I.; LANGBEEN, A.; LEROY, J. High throughput noninvasive oocyte quality assessment: the search continues. Animal. Reproduction, Belo Horizonte, v. 9, n. 3, p. 420425, 2012.

BRAGANCA, G. M.; BATISTA, R.; SOUZA-FABJAN, J. M. G.; ALFRADIQUE, V. A. P.; ARASHIRO, E. K. N.; COSENTINO, I. O.; PINTO, P. H. N.; CAMARGO, L. S. A.; FONSECA, J. F. da; BRANDAO, F. Z. Dose and administration protocol for FSH used for ovarian stimulation affect gene expression in sheep cumulus-oocyte complexes. Reproduction Fertility and Development, East Melbourne, v. 30, n. 9, p. 1234-1244, 2018. DOI: $10.1071 / \mathrm{RD} 17337$

CASTANEDA, C. A.; KAYE, P.; PANTALEON, M.; PHILLIPS, N.; NORMAN, S.; FRY, R.; D'OCCHIO, M. J. Lipid content, active mitochondria and brilliant cresyl blue staining in bovine oocytes. Theriogenology, New York, v. 79, n. 3, p. 417-422, 2013. DOI: 10.1016/j. theriogenology.2012.10.006

CATALA, M. G.; IZQUIERDO, D.; UZBEKOVA, S.; MORATO, R.; ROURA, M.; ROMAGUERA, R.; PAPILLIER, P.; PARAMIO, M. T. Brilliant Cresyl Blue stain selects largest oocytes with highest mitochondrial activity, maturation-promoting factor activity and embryo developmental competence in prepubertal sheep. Reproduction, Bristol, v. 142, n. 4, p. 517-527, 2011. DOI: 10.1530/REP-10-0528

DE BEM, T.; ADONA, P. R.; BRESSAN, F. F.; MESQUITA, L. G.; CHIARATTI, M. R.; MEIRELLES, F. V.; LEAL, C. The influence of morphology, follicle size and Bcl-2 and Bax transcripts on the developmental competence of bovine oocytes. Reproduction in Domestic Animals, Berlin v. 49, n. 4, p. 576-583, 2014. DOI: 10.1111/rda. 12325

DE LOOS, F.; VAN MAURIK, P.; VAN BENEDEN, T.; KRUIP, T. A. Structural aspects of bovine oocyte maturation in vitro. Molecular Reproduction and Development, Hoboken, v. 31, n. 3, p. 208-214, 1992. DOI: $10.1002 / \mathrm{mrd} .1080310308$

DUARTE ALCOBA, D.; GONSALES VALERIO, E.; CONZATTI, M.; SCHNEIDER, J.; CAPP, E.; VON EYE CORLETA, H.; BRUM, I. S. Selection of developmentally competent human oocytes aspirated during cesarean section. The Journal of MaternalFetal \& Neonatal Medicine, London, v. 31, n. 6, p. 735-739, 2018. DOI: 10.1080/14767058.2017.1297405

FANG, X.; XIA, W.; CAO, H.; GUO, Y.; WANG, H.; ZHANG, X.; WAN, P.; LIU, C.; WEI, Q.; SUN, S.; TIAN, S.;LI, J.;WANG,Z.Effect of supplemetation ofZebularine and Scriptaid on efficiency of in vitro developmental competence of ovine somatic cell nuclear transferred embryos. Animal Biotechnology, Abingdon, v. 30, n. 8, p. 1-9, 2019. DOI: 10.1080/10495398.2018.1559846

FATHI, M.; ASHRY, M.; SALAMA, A.; BADR, M. R. Developmental competence of Dromedary camel (Camelus dromedarius) oocytes selected using brilliant cresyl blue staining. Zygote, Cambridge, v. 25, n. 4, p. 529-536, 2017. DOI: 10.1017/S0967199417000387 
GANDOLFI, T. A.; GANDOLFI, F. The maternal legacy to the embryo: cytoplasmic components and their effects on early development. Theriogenology, New York, v. 55 , n. 6 , p. $1255-1276,2001$. DOI: 10.1016/S0093691X(01)00481-2

HOLM, P.; BOOTH, P. J.; SCHMIDT, M. H.; GREVE, T.; CALLESEN, H. High bovine blastocyst development in a static in vitro production system using SOFaa medium supplemented with sodium citrate and myoinositol with or without serum-proteins. Theriogenology, New York, v. 52, n. 4, p. 683-700, 1999. DOI: 10.1016/ S0093-691X(99)00162-4

HYTTEL, P.; FAIR, T.; CALLESEN, H.; GREVE, T. Oocyte growth, capacitation and final maturation in cattle. Theriogenology, New York, v. 47, n. 1, p. 23-32, 1997. DOI: $10.1016 /$ S0093-691X(96)00336-6

IWASAKI, W.; YAMANAKA, K.; SUGIYAMA, D.; TESHIMA, Y.; BRIONES-NAGATA, M. P.; MAEKI, M.; YAMASHITA, K.; TAKAHASHI, M.; MIYAZAKI, M. Simple separation of good quality bovine oocytes using a microfluidic device. Scientific Reports, London, v. 8 , n. 1 , p. $142-173$, 2018. DOI: $10.1038 / \mathrm{s} 41598-018-$ 32687-6

KARAMI SHABANKAREH, H.; AZIMI, G.; TORKI, M. Developmental competence of bovine oocytes selected based on follicle size and using the brilliant cresyl blue (BCB) test. Iranian Journal of Reproductive Medicine, Yazd, v. 12, n. 11, p. 771-778, 2014.

KAUFFOLD, J.; AMER, H. A.; BERGFELD, U.; WEBER, W.; SOBIRAJ, A. The in vitro developmental competence of oocytes from juvenile calves is related to follicular diameter. Journal of Reproduction and Development, Tokyo, v. 51, n. 3, p. 325-332, 2005. DOI:10.1262/jrd.17002

KIM, J.; YOU, J.; HYUN, S. H.; LEE, G.; LIM, J.; LEE, E. Developmental competence of morphologically poor oocytes in relation to follicular size and oocyte diameter in the pig. Molecular Reproduction and Development, Hoboken, v. 77, n. 4, p. 330-339, 2010. DOI: 10.1002/ mrd.21148

LABRECQUE, R.; FOURNIER, E.; SIRARD, M. A. Transcriptome analysis of bovine oocytes from distinct follicle sizes: Insights from correlation network analysis. Molecular Reproduction and Development, Hoboken, v. 83 , n. 6, p. 558-569, 2016. DOI: $10.1002 / \mathrm{mrd} .22651$

LIU, X. M.; WANG, Y. K.; LIU, Y. H.; YU, X. X.; WANG, P. C.; LI, X.; DU, Z. Q.; YANG, C. X. Single-cell transcriptome sequencing reveals that cell division cycle 5-like protein is essential for porcine oocyte maturation. Journal of Biological Chemistry, Baltimore, v. 293, n. 5, p. $1767-1780,2018$. DOI: 10.1074/jbc.M117.809608

MIRSHAMSI, S. M.; KARAMISHABANKAREH, H.; AHMADI-HAMEDANI, M.; SOLTANI, L.; HAJARIAN, H.; ABDOLMOHAMMADI, A. R. Combination of oocyte and zygote selection by brilliant cresyl blue (BCB) test enhanced prediction of developmental potential to the blastocyst in cattle. Animal Reproduction Science, Amsterdam, v. 136, n. 4, p. 245251, 2013. DOI: 10.1016/j.anireprosci.2012.11.002

MOHAMMADI-SANGCHESHMEH, A.; SOLEIMANI, M.; DELDAR, H.; SALEHI, M.; SOUDI, S.; HASHEMI, S. M.; SCHELLANDER, K.; HOELKER, M. Prediction of oocyte developmental competence in ovine using glucose-6-phosphate dehydrogenase (G6PDH) activity determined at retrieval time. Journal of Assisted Reproduction Genetics, Amsterdam, v. 29, n. 2, p. 153 158, 2012. DOI: $10.1007 / \mathrm{s} 10815-011-9625-6$

OPIELA, J.; KATSKA-KSIAZKIEWICZ, L. The utility of Brilliant Cresyl Blue (BCB) staining of mammalian oocytes used for in vitro embryo production (IVP). Reproductive Biology, Olsztyn, v. 13, n. 3, p. 177-183, 2013. DOI: $10.1016 /$ j.repbio.2013.07.004

PARRISH, J. J. Bovine in vitro fertilization: in vitro oocyte maturation and sperm capacitation with heparin. Theriogenology, New York, v. 81, n. 1, p. 67-73, 2014. DOI: $10.1016 /$ j.theriogenology.2013.08.005

PONTES, J. H.; MELO STERZA, F. A.; BASSO, A. C.; FERREIRA, C. R.; SANCHES, B. V.; RUBIN, K. C.; SENEDA, M. M. Ovum pick up, in vitro embryo production, and pregnancy rates from a large-scale commercial program using Nelore cattle (Bos indicus) donors. Theriogenology, New York, v. 75, n. 9, p. 16401646, 2011. DOI: 10.1016/j.theriogenology.2010.12.026

PUJOL, M.; LOPEZ-BEJAR, M.; PARAMIO, M. T. Developmental competence of heifer oocytes selected using the brilliant cresyl blue (BCB) test. Theriogenology, New York, v. 6, n. 4, p. 735-744, 2004. DOI: 10.1016/ S0093-691X(03)00250-4

RODRIGUEZ-GONZALEZ, E.; LOPEZ-BEJAR, M.; VELILLA, E.; PARAMIO, M. T. Selection of prepubertal goat oocytes using the brilliant cresyl blue test. Theriogenology, New York, v. 57, n. 5, p. 13971409, 2002. DOI: $10.1016 / \mathrm{S} 0093-691 \mathrm{X}(02) 00645-3$

SOARES, M. M.; CÁSSIA ANTONINO, D. de; OLIVEIRA, M.; MELO JUNIOR, J.; PEIXOTO, L. R.; MAIA, T. S.; ALVES, K. A.; JACOMINI, J. O.; SANTOS, R. M. dos; MACEDO, G. G. The role of Kisspeptin in bovine in vitro embryo production. Semina: Ciências Agrárias, Londrina, v. 39, n. 2, p. 621630, 2018. DOI: 10.5433/1679-0359.2018v39n2p621 
SOVERNIGO, T. C.; ADONA, P. R.; MONZANI, P. S.; GUEMRA, S.; BARROS, F.; LOPES, F. G.; LEAL, C. Effects of supplementation of medium with different antioxidants during in vitro maturation of bovine oocytes on subsequent embryo production. Reproduction Domestic Animals, Berlin, v. 52, n. 4, p. 561-569, 2017. DOI: $10.1111 /$ rda.12946
SU, J.; WANG, Y.; LI, R.; PENG, H.; HUA, S.; LI, Q.; QUAN, Q.; GUO, Z.; ZHANG, Y. Oocytes selected using $\mathrm{BCB}$ staining enhance nuclear reprogramming and the in vivo development of SCNT embryos in cattle. PLoS One, San Francisco, v. 7, n. 4, p. 361-381, 2012. DOI: 10.1371 journal.pone.0036181 
